\title{
Administration of Cannabis Causes Alterations in Monoamine Oxidase B and Serotonin Receptor 2c Gene Expressions in Wistar Rats
}

\author{
Oluwatosin Adebisi Dosumu ${ }^{1}$, Oluwafemi Paul Owolabi ${ }^{1}$, Regina Ngozi Ugbaja ${ }^{1}$, \\ Akinola Popoola ${ }^{2}$, Solomon Oladapo Rotimi ${ }^{3}$, Odunayo Anthonia Taiwo ${ }^{1,4}$, \\ Oluwafemi Adeleke Ojo ${ }^{5}$ \\ ${ }^{1}$ Department of Biochemistry, Federal University of Agriculture, Abeokuta, Nigeria \\ ${ }^{2}$ Department of Crop Protection, Federal University of Agriculture, Abeokuta, Nigeria \\ ${ }^{3}$ Department of Biochemistry, Covenant University, Sango Ota, Nigeria \\ ${ }^{4}$ Department of Biochemistry, Chrisland University, Abeokuta, Nigeria \\ ${ }^{5}$ Department of Biochemistry, Landmark University, Omu-Aran, Nigeria
}

\section{SUMMARY}

This study examined the probable effects of graded doses of Cannabis sativa (C. sativa) extract on the gene expressions of monoamine oxidase B and serotonin receptor 2C (HTR2C) in an attempt to correlate the duration of use with neurodegeneration tendencies in chronic marijuana users. Male Wistar rats weighing between $90 \mathrm{~g} \pm 100 \mathrm{~g}$ were treated with graded doses of petroleum ether extract of $C$. sativa $(12.5,25$ and $50 \mathrm{mg} / \mathrm{kg}$ body weight) orally. The exposure was monitored at 4, 8, and 12 weeks for each of the doses employed, after which the brain was removed. The gene expressions were determined by reverse transcriptase polymerase chain reaction. Cannabis considerably $(p<0.05)$ reduced the relative expression of MAOB at 4 weeks. At 8 weeks, cannabis upregulated the relative expression of the MAOB gene by $60 \%$. Following 12 weeks of exposure to the $50 \mathrm{mg} / \mathrm{kg}$ body weight dose of $C$. sativa, $80 \%$ increase in the expression of MAOB was observed compared to the control group. C. sativa $(50 \mathrm{mg} / \mathrm{kg}$ body weight) extract at 8 weeks resulted in about $47.7 \%$ decrease in the expression of the gene, however, prolonged exposure $(12$ weeks) to the extract significantly $(p<0.05)$ increased the relative expression of HTR2C. Cannabis-induced dysregulation of the MAOB genes may be one mechanism linking chronic use of cannabis to cognitive decline and improved likelihood of developing neurological diseases. Alterations observed in HTR2C gene expression as a result of exposure to high doses of $C$. sativa extract may partly account for the depression and aggressive tendencies observed in chronic users.

Key words: MAOB, gene expression, HTR2C, Cannabis, neurodegeneration

Corresponding author:

Oluwafemi Paul Owolabi and Oluwafemi Adeleke Ojo

e-mail: fm_owolabi@yahoo.com and ojo.adeleke@lmu.edu.ng 


\section{INTRODUCTION}

Marijuana, otherwise called cannabis, is a preparation of the Cannabis plant proposed for use as a psychoactive medication. It is for the most part utilized recreationally or as restorative medication. Research on cannabinoids has been growing significantly with more than $50 \%$ of this research corresponding to "cannabinoids and brain", particularly relating to neurodegeneration (1). With this, there is proof that particular phytocannabinoids give some particular activities on every single one of the pathogenic systems engaged in neurodegeneration, for example, neuro-inflammation, oxidative stress and excitotoxicity (1).

Monoamine oxidase $\mathrm{B}$, otherwise called $\mathrm{MAOB}$, is an enzyme in people encoded by the MAOB gene. The protein encoded by this gene has a place in the flavin monoamine oxidase family. It is a protein located in the outer mitochondrial layer where it catalyzes the oxidative deamination of biogenic and xenobiotic amines and shoulders a noteworthy role in the catabolism of neuroactive and vasoactive amines in the focal sensory system and peripheral tissues (2). Like monoamine oxidase A (MAOA), it additionally debases dopa disease $(2,3)$. Vague (for example MAOA/B consolidated) inhibitors can present issues when taken associatively with tyramine-containing nourishments, for example, cheese, because the hindrance of MAOA by the medications causes a hazardous rise of serum tyramine levels, which can prompt hypertensive side effects.

Particular MAOB inhibitors sidestep this issue by specially repressing $\mathrm{MAOB}$, which for the most part utilizes dopamine. If MAOB is repressed, at that point more dopamine is accessible for legitimate neuronal capacity, particularly in Parkinson's disease. Alzheimer's and Parkinson's diseases are both related to raised degrees of MAOB in the cerebrum $(4,5)$. The ordinary action of MAOB makes responsive oxygen species, which straightforwardly harm cells (6). MAOB levels have been found to increment with age, suggesting a part in normal agerelated intellectual decay and the improved probability of creating neurological ailments, sometimes, down the road (7). More dynamic polymorphisms of the MAOB genes have been connected to negative emotionality and are suspected as a fundamental factor in depression (8). The action of MAOB has additionally appeared to assume a role in pressureinitiated heart harm (9).

Serotonin (5-hydroxytryptamine (5-HT)) has been involved in a wide scope of mental issues and in very explicit standards of conduct, chiefly described by a helpless control of driving forces (10). It is one of the most novel and pharmacologically complex monoamines in both the fringe and focal sensory system and hence has become the focal point of enthusiasm for the treatment of depression with numerous serotonin-mimetic and modulators of grown-up neurogenesis clinically (11).

Serotonin 2C (HTR2C) receptor is a subtype of 5-HT receptor that ties the endogenous synapse serotonin (5-hydroxytryptamine, 5-HT). It is a G protein-coupled receptor (GPCR) that intercedes excitatory neurotransmission. HTR2C signifies the gene encoding for the receptor (12). The HTR2C receptor is one of the many restricting destinations for serotonin. The initiation of this receptor by serotonin restrains dopamine and norepinephrine discharge in specific zones of the cerebrum (13). HTR2C receptors are guaranteed to essentially direct state of mind, uneasiness, taking care of, and conceptive conduct (14). Musty and Kaback (15) recommended that cannabis may have some inhibitory role on serotonin which may prompt inactivation of HTR2C receptor resulting in the lack of motivation and depression symptoms in cannabis users. Be that as it may, data are deficient on the impact of cannabis on the modulatory job of serotonin receptors in the cerebrum. It was in this way important to research the impacts of various dosages of cannabis on the gene articulations of MAOB and HTR2C.

\section{MATERIALS AND METHODS}

\section{Collection and extraction of Cannabis sativa}

Marijuana was obtained from the National Drug Law Enforcement Agency (NDLEA). It was air-dried at room temperature and pulverized using a clean, dry electric blender. Milled marijuana (250 g) was soaked in $1000 \mathrm{ml}$ of petroleum ether in a round bottom flask for 24 hours, after which it was decanted and the filtrate kept. Fresh $500 \mathrm{ml}$ of petroleum ether was added to the residue. This was repeated until the filtrate was colorless. The filtrate was concentrated using a rotary evaporator at $40^{\circ} \mathrm{C}$. The concentrated extract was dissolved in olive oil at 
$50 \mathrm{mg} / \mathrm{ml}$ and kept in a dark bottle to prevent photolysis and was stored at $25^{\circ} \mathrm{C}$.

\section{Animals}

A total of sixty male Wistar rats (90 - $100 \mathrm{~g}$ ) were utilized for this experiment. The rats were kept in clean confines, exposed to 12-h light and dark cycles, and had free access to food and water ad libitum. The animals were permitted to adapt to their condition for about fourteen days before the test began. This study was performed, and rats were cared for following the declaration of Helsinki. The ethical approval for this study was obtained from the University ethical committee with the approval number 2016-06-14/0520.

Treatment protocol and tissue collection

The animals were divided into twelve (3 control and 9 test groups) groups of 5 animals each. The control groups were administered $1 \mathrm{~mL} / \mathrm{kg}$ body weight of olive oil and the test groups took 12.5, 25, and $50 \mathrm{mg} / \mathrm{kg}$ body weight of the marijuana extract. The exposure was monitored at 4, 8, and 12 weeks for each of the doses employed as described by Dosumu et al. (16). The test groups were administered $12.5,25$, and $50 \mathrm{mg} / \mathrm{kg}$ body weight marijuana extract for 4, 8, and 12 weeks. Each group of animals was sacrificed after an overnight fast using diethyl-ether anesthesia at the end of the exposure time. The brain was excised from the animal and placed in RNAlater ${ }^{\circledR}$.

\section{Biochemical analysis}

Extraction of RNA

RNA was obtained from RNAlater ${ }^{\circledR}$ - stabilized the brain via the Aidlab spin column RNA extraction pack as indicated by the guidelines of the producer. The concentration and clarity of obtained RNA were resolved at $260 \mathrm{~nm}$ and $280 \mathrm{~nm}$ utilizing a NanoDrop $^{\circledR} 2000$ spectrophotometer (Thermo Scientific). RNA tests were preserved at $-80^{\circ} \mathrm{C}$ for gene expression analysis.

Expression of monoamine oxidase $\mathrm{B}$ and serotonin receptor $2 \mathrm{C}$ genes

The levels of expression of monoamine oxidase $b$ gene were assessed in the brain using SDi quantitative reverse transcriptase-polymerase chain reaction (RT-PCR). The RT-PCR was done with 500 ng RNA template utilizing TranGen EasyScript onestep RT-PCR pack as indicated by the maker's directions. The RNA samples were exposed to an initial $30 \mathrm{~min}$ steam bath at $45^{\circ} \mathrm{C}$ for cDNA synthesis after which PCR amplification was done, utilizing gene-specific primers (GSP) (Table 1), at $94^{\circ} \mathrm{C}$ for 5 min trailed by 40 cycles of $94^{\circ} \mathrm{C}$ for $30 \mathrm{~s}, 5 \mathrm{~min}$ at the annealing temperature of GSP, and $1 \mathrm{~min}$ at $72^{\circ} \mathrm{C}$.

All amplifications were done in C1000 Touch $^{\mathrm{TM}}$ Thermal Cycler (Bio-Rad Laboratories, Hercules, CA). After PCR, amplicons were envisioned on $1.2 \%$ agarose gel in $1 \mathrm{X}$ Tris Borate EDTA buffer utilizing UVP BioDoc-It-TM Imaging system

Table 1. Sequences of gene-specific primer

\begin{tabular}{l|l|l}
\hline \hline Gene Specific Primers & Sequence (5` $\left.\mathbf{3} \mathbf{3}^{\prime}\right)$ & Template \\
\hline \multirow{2}{*}{ Monoamine Oxidase B } & Forward: TTTGGCAGCCAGAACCAGAA & \multirow{2}{*}{ NM_024395.1 } \\
\cline { 2 - 2 } & Reverse: AGCTTGTGTTCCAGTCACCC & \\
\hline \multirow{2}{*}{ Serotonin Receptor 2C } & Forward: ATCGGCCTATTGGTTTGGCA & \multirow{2}{*}{ NM_012765.5 } \\
\cline { 2 - 2 } & Reverse: GCGCAGGACGTAGATCGTTA & \\
\hline \multirow{3}{*}{-Actin } & Forward: GTCAGGTCATCACTATCGGCAAT & \multirow{2}{*}{ NM_031144.3 } \\
\cline { 2 - 2 } & Reverse: AGAGGTCTTTACGGATGTCAACGT & \\
\hline \hline
\end{tabular}

(Upland, CA, USA). The intensity of the bands was analyzed utilizing Image J software as depicted by Abramoff et al. (17). Results were displayed as rela- tive expression (ratio of the intensity of each gene to that of $\beta$-actin, Actb) of each gene in comparison with housekeeping ( $\beta$-actin, Actb) gene. 


\section{DATA ANALYSIS}

All the values were expressed as mean $\pm \mathrm{SD}$ ( $\mathrm{n}$ $=6$ ). Statistical analyses was done using Statistical Package for Social Science (SPSS) 20.0 edition software. The groups were compared using one-way analysis of variance (ANOVA) followed by Tukey's test as a post hoc analysis. A value of $p<0.05$ was considered statistically significant.

\section{RESULTS}

Figure 1 depicts the gas chromatography-mass spectroscopy of marijuana extract using petroleum ether as the extraction solvent. The result shows that the extract contains about $60.36 \%$ of cannabinol (31.543) in the extract, while other constituents in the extract are $7 \%$ or less. Table 2 shows the compound identified by the GC-MS spectrum of marijuana ex-

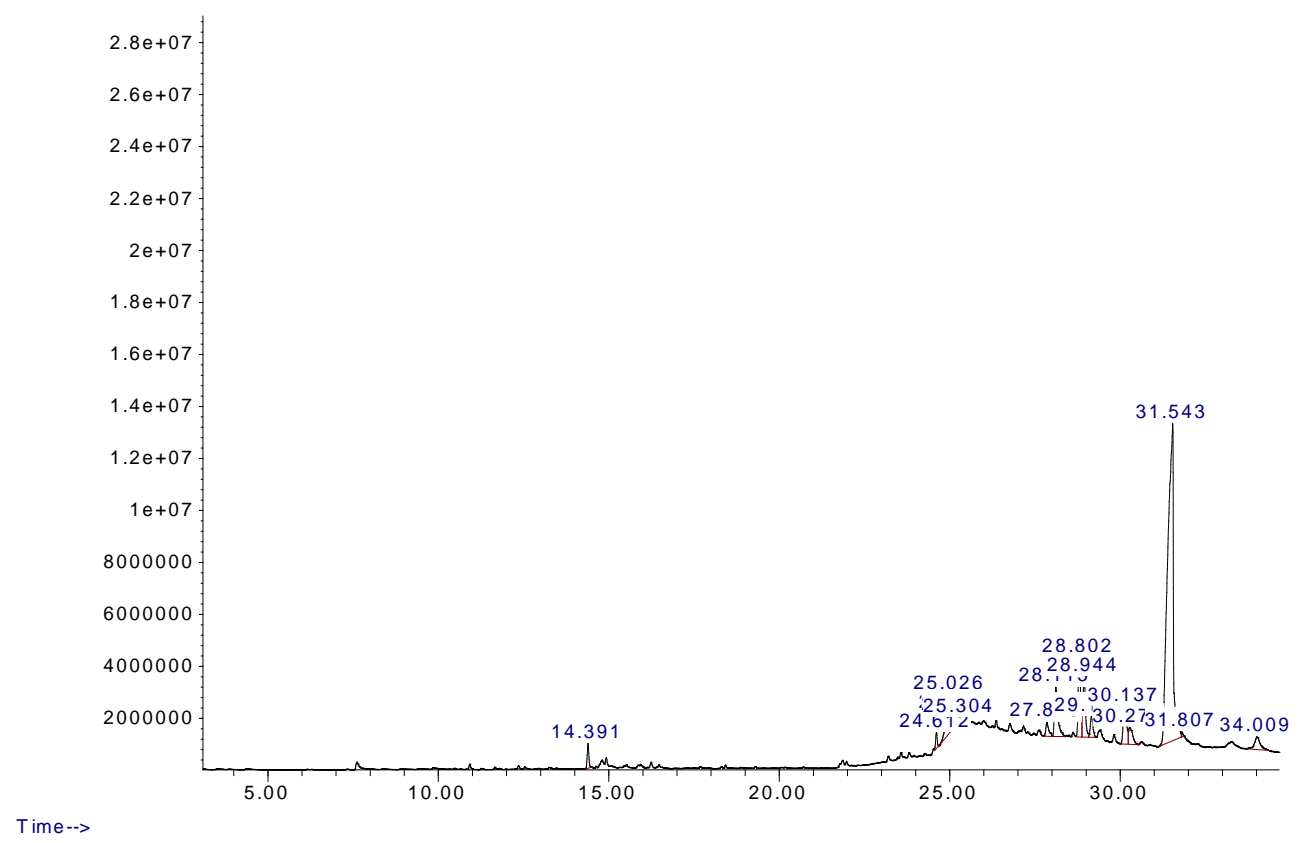

Figure 1. GC-MS spectrum of marijuana extract

Table 2. Compounds identified by GC-MS in marijuana extract

\begin{tabular}{l|l|l|l}
\hline \hline S/N & ID Number & Name of compound & \% Proportion \\
\hline 1 & 14.391 & 8a-Methyl-5-methylene-3-(prop-1-en-2-yl)- & $1.341 \%$ \\
\hline 2 & 24.612 & Ethyl Oleate-9-Tetradecenal, (Z)-Cyclopropaneoctanal & $0.811 \%$ \\
\hline 3 & 25.025 & $9,12-$ Octadecadienoic acid (Z,Z) & $7.210 \%$ \\
\hline 4 & 25.178 & Linoelaidic acid & $0.67 \%$ \\
\hline 5 & 27.846 & Cannabichromene & $1.134 \%$ \\
\hline 6 & 28.115 & 5H-Naphtho[2,3-c]carbazole & $5.362 \%$ \\
\hline 7 & 28.941 & Cannabicoumaronone & $6.386 \%$ \\
\hline 8 & 28.944 & Morphinan-6-one & $5.327 \%$ \\
\hline 9 & 30.134 & Dronabinol & $4.124 \%$ \\
\hline 10 & 30.272 & 6-Methyl-2-phenyl-7-phenylmethylin dolizine & $2.296 \%$ \\
\hline 11 & 31.543 & Cannabinol & $60.363 \%$ \\
\hline 12 & 31.805 & Cannabinol & $0.202 \%$ \\
\hline 13 & 34.008 & Sterigmatocystin & $4.12 \%$ \\
\hline \hline
\end{tabular}



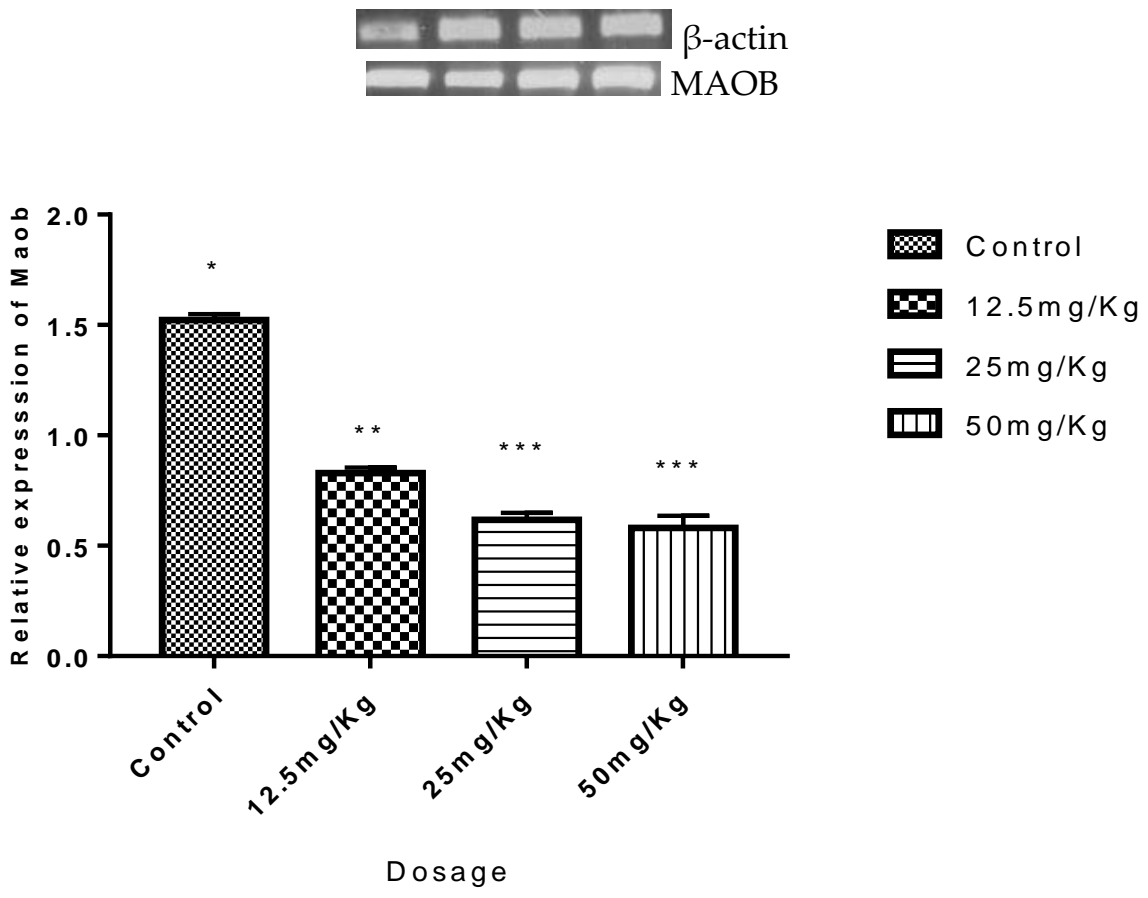

A

Figure 2. A bar graph showing the effects of marijuana on the relative expression of $M A O B$ gene:

(A) $M A O B$ expression at 4 weeks
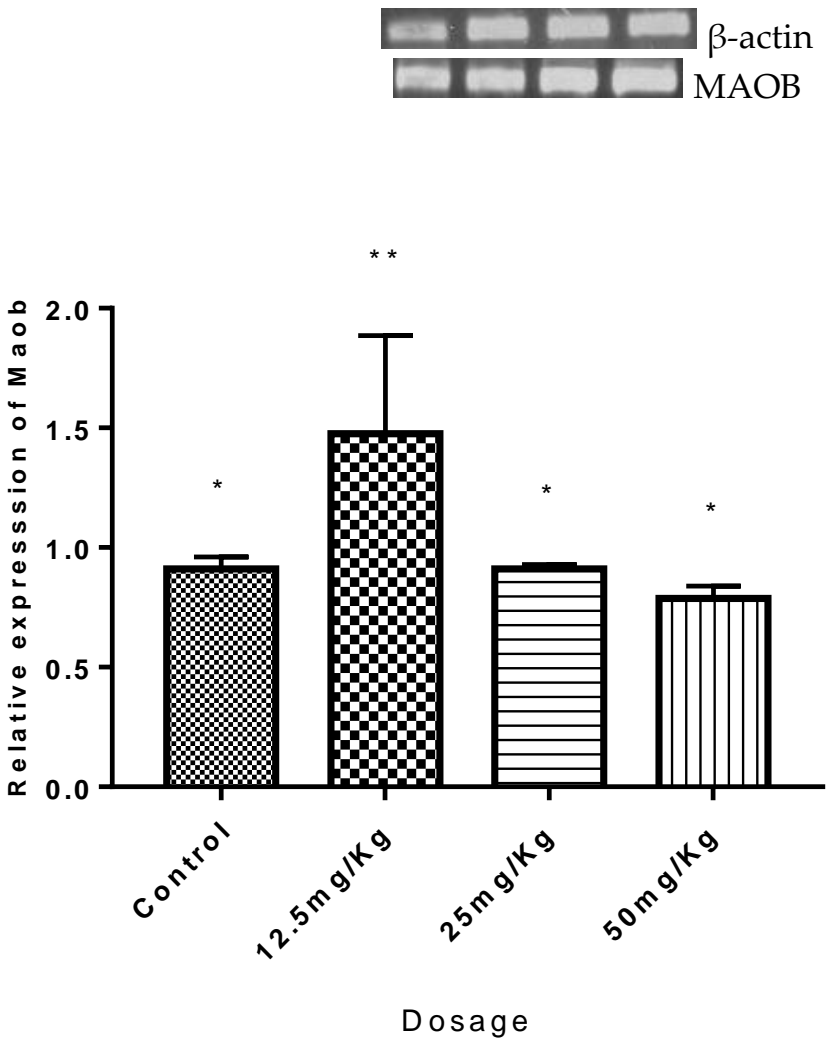

Q Control

Ex $12.5 \mathrm{mg} / \mathrm{Kg}$

曰 $25 \mathrm{mg} / \mathrm{Kg}$

피 $50 \mathrm{mg} / \mathrm{Kg}$

B

Figure 2. (B) $M A O B$ expression at 8 weeks 


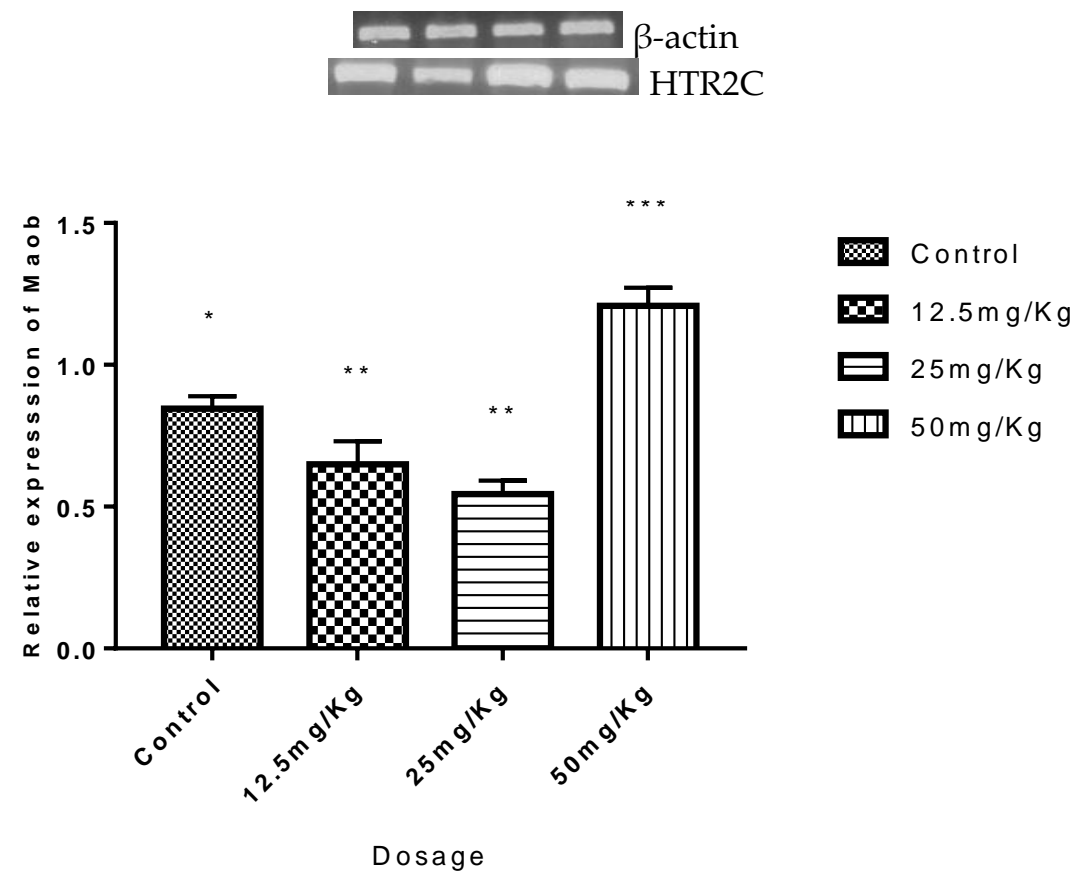

C

Figure 2. (C) $M A O B$ expression at 12 weeks. Bars represent the means $\pm S D(n=5)$. Relative expression is the ratio of intensity of each gene to that of the housekeeping gene ( $\beta$-actin, Actb). ${ }^{* *} p<0.0001,{ }^{* * *} p<0.0002$ when compared with control group.
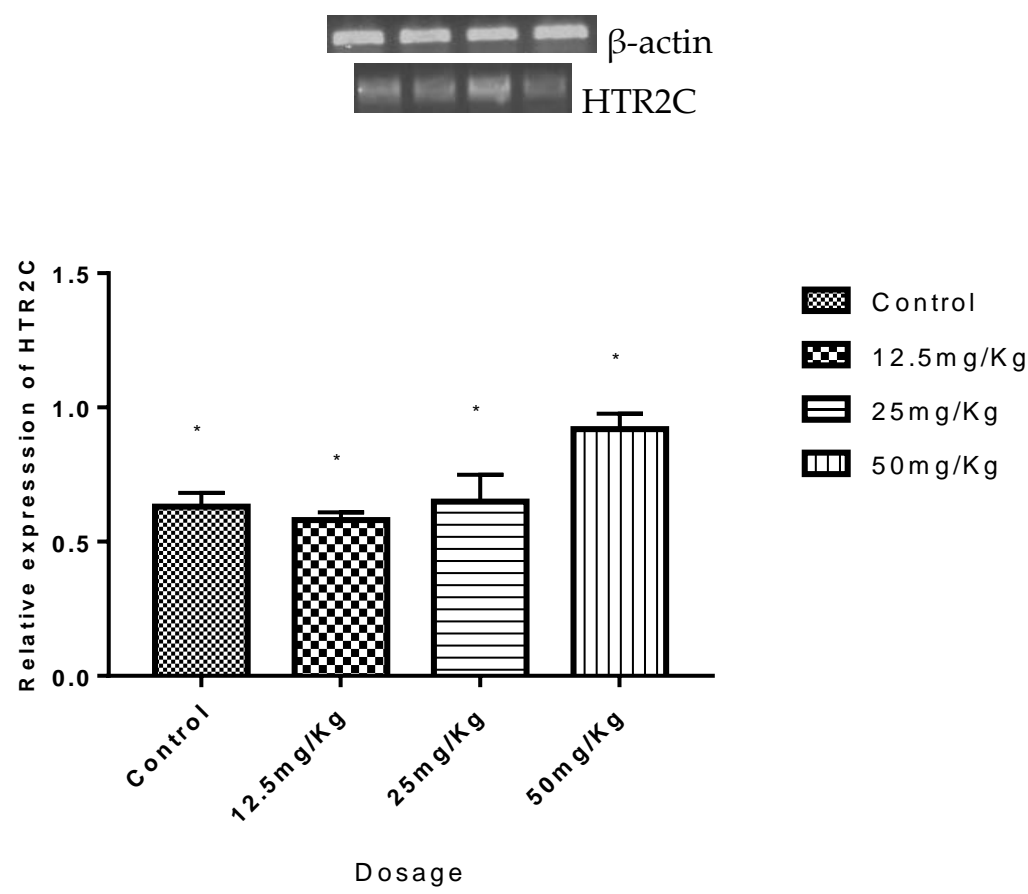

A

Figure 3. A bar graph showing the effects of marijuana on the relative expression of HTR2C gene:

(A) HTR2C expression at 4 weeks 

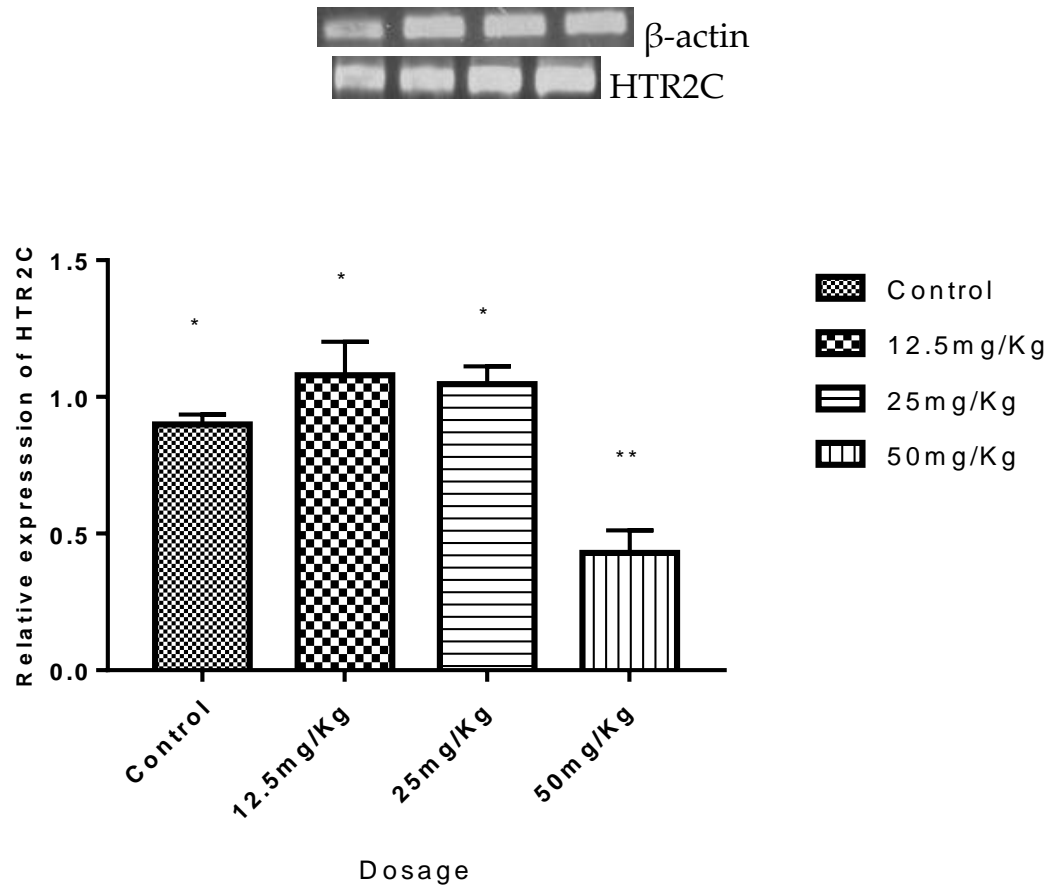

B

Figure 3. (B) HTR2C expression at 8 weeks
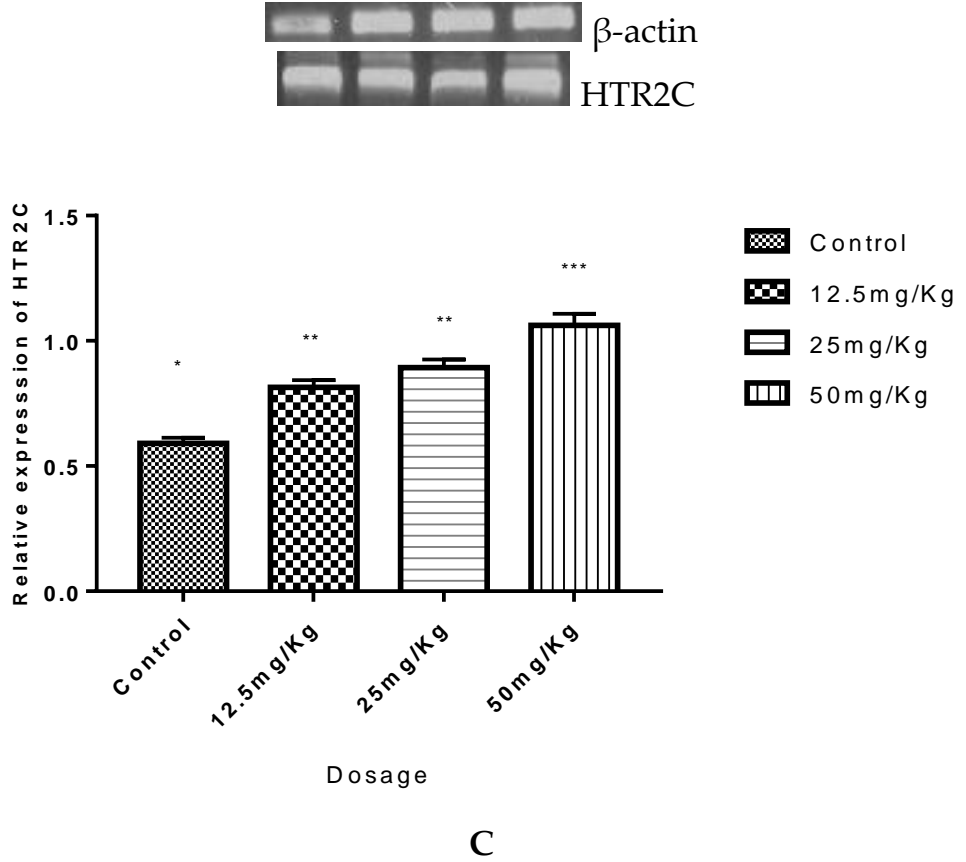

Figure 3. (C) HTR2C expression at 12 weeks. Bars represent the means $\pm S D(n=5)$. Relative expression is the ratio of intensity of each gene to that of the housekeeping gene ( $\beta$-actin, Actb). ${ }^{* *} p<0.01,{ }^{* * *} p<0.002$ when compared with control group. 
tract and its percentage composition.

In Figure 2, the expression of the gene was examined in brain samples from all treatment groups. At 4 weeks, the relative expression of the MAOB gene significantly $(p<0.05)$ decreased (Fig. 2a). At 8 weeks, the relative expression of MAOB gene significantly $(p<0.05)$ increased only in the group administered $12.5 \mathrm{mg} / \mathrm{kg}$ body weight dose when compared with the control group (Fig. 2b). At 12 weeks, the relative expression of MAOB gene considerably $(\mathrm{p}<0.05)$ decreased in the group administered 12.5 and $25 \mathrm{mg} / \mathrm{kg}$ body weight dose when compared with the control group. Administration of $50 \mathrm{mg} / \mathrm{kg}$ body weight dose of marijuana resulted in about an $80 \%$ increase in the relative expression of MAOB gene compared with the control group (Fig. 2c).

In Figure 3, the expression of HTR2C gene was examined in the brain of all treatment groups. At 4 weeks, noteworthy changes were not observed in the relative expression of the HTR2C compared with the control (Fig. 3a). At 8 weeks, $50 \mathrm{mg} / \mathrm{kg}$ body weight dose of C. sativa has resulted in about $47.7 \%$ decrease in the relative expression of the HTR2C gene (Fig. 3b). Prolonged exposure (12 weeks) to the extract, however, significantly $(\mathrm{p}<0.05)$ increased the relative expression of HTR2C in a dosedependent manner (Fig. 3c).

\section{DISCUSSION}

The current investigation shows the impacts of cannabis on MAOB and HTR2C gene expression in the brain. Brain monoamines are associated with huge numbers of similar cycles influenced by neuropsychiatric problems and psychotropic medications, including cannabinoids. The outcome of this study shows that the impact of cannabis on the expression of the MAOB gene is dose- and duration-dependent, however, prolonged exposures at high doses increase the expression. The result shows that the relative expression of MAOB gene considerably ( $\mathrm{p}<$ $0.05)$ decreased compared with the control group at 4 weeks. The downregulation of MAOB genes at 4 weeks suggest the utilization of low portions of cannabis as an antidepressant in patients (18). Monoamine oxidase inhibitors are normally utilized in the management of melancholy, and MAOB inhibitors are commonly utilized in the treatment of Parkinson's disease (3) as Alzheimer's malady and Parkinson's ailment have both been related with raised degrees of MAOB in the brain (5). Nonetheless, it was observed in this study that administration of 50 $\mathrm{mg} / \mathrm{kg}$ body weight dose of marijuana resulted in about an $80 \%$ increase in the relative expression of MAOB compared with the control group. Expanded MAOB levels as observed from this investigation have been accounted for to play out a role in intellectual decay and the improved probability of creating neurological sicknesses in chronic cannabis users (7). This result supports the result uncovered by Gruber et al. that cannabis intensifies depression at high doses and other mental conditions (19).

Increased action of MAOB makes reactive oxygen species, which prompts oxidative and additionally nitrosative stress in the cerebrum and legitimately harm cells (6). More dynamic polymorphisms of the MAOB gene have been connected to negative emotionality and are suspected as a fundamental aspect in despondency (8). The impact of cannabis on MAOB gene expression in the brain from this investigation, for the most part, demonstrates to be portion and span subordinate, which will likewise influence the serotonergic framework.

From this study, differential expression of HTR2C was seen at various duration. It was seen that the interminable introduction of cannabis extract to the rats essentially increased the relative expression of the HTR2C gene as the dose expanded. HTR2C receptor is a major restricting locale for serotonin. Disabled serotonin signaling is integral to depression and nervousness issues, however, it could likewise assume a significant role in the pathogenesis of a few age-related issues, comprising insulin resistance syndrome, Alzheimer's, and Huntington's diseases (16). From this study, high doses of cannabis increase the relative expression of the HTR2C gene. This increase results in the activation of the receptor gene. Activation of this receptor by serotonin hinders dopamine and norepinephrine discharge in specific regions of the brain (13). HTR2C receptors control dopamine discharge in the amygdala, hippocampus, striatum, prefrontal cortex, nerve centre, and nucleus accumbens among others. This study suggests that prolonged exposure to cannabis may bring about diminished dopamine and norepinephrine delivered in the brain as studies show that actuation of the receptor restrains the delivery as suggested by Alex et al. (13). HTR2C receptors are claimed to fundamentally manage mood, tension, feeding, and reproductive conduct (14). Exploration shows that suicide casualties have 
anomalous significant levels of HTR2C receptors in the prefrontal cortex (20). Anja et al. (21), recommended that the differential expression of HTR2C is especially significant for the improvement of new antipsychotic medication.

Numerous human polymorphisms have been distinguished impacting the outflow of HTR2C. Huge connections are proposed, explicitly comparable to psychiatric disorders, for example, depression, OCD, and tension-related conditions. Polymorphisms additionally relate with the weakness of various conditions including drug misuse (22). Evidence proposes that HTR2C is one of the genes that assume a basic job in the pathophysiology of mental issues, for example, schizophrenia (SZ), significant dejection, and bipolar disorder (BD) (23). In animal models, mice insufficient of HTR2C demonstrated a few social changes, for example, improved investigation of a novel domain (24) and dysregulation of anxiety-related practices (14). These outcomes firmly set up the association of these genes in the pathophysiology of mental issues. In this study, there was a differential relationship observed between MAOB and HTR2C expressions such that as MAOB decreases, HTR2C increases, and vice versa. Anja et al. who examined biological psychiatry uncovered that two genes were differentially communicated: $\mathrm{MAOB}$ was essentially increased in schizophrenia cerebrum, while HTR2C was fundamentally diminished (21). This study demonstrates that a few impacts of cannabinoids on brain capacities could be identified with a non-receptor balance of monoaminergic neurotransmission. For psychoactive drugs such as can- nabis, which are highly bound to fat tissues, lipid bilayers, and plasma proteins, the relative proportion of free to bound medication is significant for setting up of brain levels. Tetrahydrocannabinol (THC) levels in the brain are higher than THC fixations in blood (25). There is no particular conveyance of THC in any territory of the brain (26), however, it was discovered that THC was collected especially in neurons (27). The chance exists that MAOB movement in this study is influenced because of the enduring activity of lipophilic cannabinoids and their collection in the mitochondrial film during chronic exposure.

\section{CONCLUSION}

Although it is consistently hard to extrapolate from in vitro studies to clinical reality, the current outcomes propose that the analyzed cannabis may contribute to an inhibitory impact on MAOB observed at low doses and acute treatment, however, a precise in vivo examination of the cannabis impact on MAOB and HTR2C is required. The specific physiological function of MAOB hindrance by cannabinoids is not known; in any case, the impacts of cannabinoids on MAOB and HTR2C action may add to non-receptor activities of cannabinoids taking an interest in the regulation of monoamine neurotransmission in the brain. It tends to be conjectured that the restraint of MAOB by cannabis could add to the guideline of mind-set and feelings or the interindividual contrasts in the medication reaction. 


\section{References}

1. Rosales-Corral S, Hernández L, Gallegos M. Cannabinoids in Neuroinflammation, Oxidative Stress and Neuro Excitotoxicity. Pharm Anal Acta 2015; 6:3.

2. Nolen WA, Hoencamp E, Bouvy P.F, Haffmans P.M. "Reversible monoamine oxidase-A inhibitors in resistant major depression". Clin Neuropharmacol1993; 16(2): S69-76.

3. Riederer P, Laux G. MAO-inhibitors in Parkinson's disease. Exp Neurobiol 2011; 20 (1): 1-17. https://doi.org/10.5607/en.2011.20.1.1

4. Saura J, Luque JM, Cesura AM, Da Prada M, Chan-Palay V, Huber G, et al. "Increased monoamine oxidase $\mathrm{B}$ activity in plaqueassociated astrocytes of Alzheimer brains revealed by quantitative enzyme radioautography".

Neuroscience 1994; 62(1): 15-30. https://doi.org/10.1016/0306-4522(94)90311-5

5. Mallajosyula JK, Chinta SJ, Rajagopalan S, Nicholls DG, Andersen JK. "Metabolic control analysis in a cellular model of elevated MAO-B: relevance to Parkinson's disease". Neurotox Res 2009; 16(3): 186-93

https://doi.org/10.1007/s12640-009-9032-2

6. Nagatsu T, Sawada M. Molecular mechanism of the relation of monoamine oxidase $\mathrm{B}$ and its inhibitors to Parkinson's disease: possible implications of glial cells. J Neural Transm Suppl 2006; 71(71): 53-65.

https://doi.org/10.1007/978-3-211-33328-0 7

7. Kumar MJ, Andersen JK.Perspectives on MAO-B in aging and neurological disease: where do we go from here? Mol Neurobiol 2004; 30(1): 77-89. https://doi.org/10.1385/MN:30:1:077

8. Dlugos AM, Palmer AA, De Wit H. Negative emotionality: monoamine oxidase $\mathrm{B}$ gene variants modulate personality traits in healthy humans. J Neural Transm 2009; 116(10): 1323-34.

\section{https://doi.org/10.1007/s00702-009-0281-2}

9. Kaludercic N, Carpi A, Nagayama $T$, Sivakumaran V, Zhu G, Lai EW, et al. Monoamine oxidase $\mathrm{B}$ prompts mitochondrial and cardiac dysfunction in pressure overloaded hearts. Antioxid Redox Signal 2014; 20(2): 267-80. https://doi.org/10.1089/ars.2012.4616

10. López-Ibor JJ. Serotonin and psychiatric disorders. Int Clin Psychopharmacol 1992; 2:5-11. https://doi.org/10.1097/00004850-199210002-00003

11. Alenina N, Klempin F. The role of serotonin in adult hippocampal neurogenesis. Behav Brain Res 2015; 277:49-57.

https://doi.org/10.1016/j.bbr.2014.07.038

12. Stam NJ, Vanderheyden $P$, Van Alebeek C, Klomp J, De Boer T, Van Delft AM, et al.. Genomic organisation and functional expression of the gene encoding the human serotonin 5-HT2C receptor. Eur J Pharmacol 1994; 269(3): 339-48. https://doi.org/10.1016/0922-4106(94)90042-6

13. Alex KD, Yavanian GJ, McFarlane HG, Pluto CP, Pehek EA. Modulation of dopamine release by striatal 5-HT2C receptors. Synapse 2005; 55(4): 242-51. https://doi.org/10.1002/syn.20109

14. Heisler LK, Zhou L, Bajwa P, Hsu J, Tecott, LH. Serotonin 5-HT (2C) receptors regulate anxietylike behavior. Genes Brain Behav 2007; 6(5): 491-6. https://doi.org/10.1111/j.1601-183X.2007.00316.x

15. Musty RE, Kaback L. Relationships between motivation and depression in chronic marijuana users.J Life Sci 1995; 56: 2151-8. https://doi.org/10.1016/0024-3205(95)00202-H

16. Dosumu OA, Taiwo OA, Akinloye OA, Oni EO, Owolabi OP, Ojo OA. Time-Course effects of Cannabis sativa on Brain Acetylcholinesterase (AChE) Activity and Expression of Dopa 
Decarboxylase Gene (DDC). Pharmacologynline 2020; 2: 302-13.

17. Abràmoff $\mathrm{MD}$, Magalhães $\mathrm{PJ}$, Ram SJ. Image processing with imageJ. Biophotonics Int 2004; 11:36-42.

18. El-Alfy, Abir T. Antidepressant-like effect of delta-9tetrahydrocannabinol and other cannabinoids isolated from Cannabis sativa L. Pharmacol Biochem Behav 2010; 95(4): 434-42. https://doi.org/10.1016/j.pbb.2010.03.004

19. Gruber AJ, Pope HG, Brown ME. Patient's use of marijuana as an antidepressant. National Institute of Health 1996; 4(2):77-80.

https://doi.org/10.1002/(SICI)15227162(1996)4:2<77::AID-DEPR7>3.0.CO;2-C

20. Niswender CM, Herrick-Davis K, Dilley GE, Meltzer HY, Overholser JC, Stockmeier CA, et al. RNA editing of the human serotonin 5-HT2C receptor. Alterations in suicide and implications for serotonergic pharmacotherapy.

Neuropsychopharmacol 2001; 24(5): 478-91. https://doi.org/10.1016/S0893-133X(00)00223-2

21. Anja C, Lina E, Rolf S, Elena J. Decrease of serotonin receptor $2 \mathrm{C}$ in schizophrenia brains identified by high-resolution mRNA expression analysis. Biol Psychia 2003; 54(11): 1212-21. https://doi.org/10.1016/S0006-3223(03)00526-2
22. Kishore S, Stamm S. The snoRNA HBII-52 regulates alternative splicing of the serotonin receptor 2C. Science 2006; 311(5758): 230-2. https://doi.org/10.1126/science.1118265

23. Kazuya I, Miki B, Tadafumi K. Serotonin receptor 2C and mental disorders: Genetic, expression, and RNA editing studies. RNA Biol 2009; 6(3):248-53 https://doi.org/10.4161/rna.6.3.8370

24. Frank MG, Stryker MP, Tecott LH. Sleep and sleep homeostasis in mice lacking the 5-HT2c receptor. Neuropsychopharmacol 2002; 27:869-73. https://doi.org/10.1016/S0893-133X(02)00353-6

25. Mura P, Kintz P, Dumestre V, Raul S, Hauet T. THC can be detected in brain while absent in blood. J Anal Toxicol 2005; 29:842-3. https://doi.org/10.1093/jat/29.8.842

26. Layman JM, Milton AS. Distribution of tritium labelled $\Delta 1$-tetrahydrocannabinol in the rat brain following intraperitoneal administration. $\mathrm{Br} \mathrm{J}$ Pharmacol 1971; 42:308-10. https://doi.org/10.1111/j.1476-5381.1971.tb07114.x

27. Monnet-Tschudi F, Hazekamp A, Perret N, Zurich MG, Mangin P, Giroud C, Honegger P. Delta-9tetrahydrocannabinol accumulation, metabolism and cell-type-specific adverse effects in aggregating brain cell cultures. Toxicol Appl Pharmacol 2008; 228:8-16.

https://doi.org/10.1016/j.taap.2007.11.007 


\title{
Aplikacija kanabisa izaziva alteraciju ekspresije gena \\ za monoamino-oksidazu i serotoninski receptor $2 \mathrm{c}$ kod pacova Wistar soja
}

\author{
Oluwatosin Adebisi Dosumu ${ }^{1}$, Oluwafemi Paul Owolabi1 ${ }^{1}$, Regina Ngozi Ugbaja1, Akinola Popoola², \\ Solomon Oladapo Rotimi ${ }^{3}$, Odunayo Anthonia Taiwo ${ }^{1,4}$, Oluwafemi Adeleke Ojo ${ }^{5}$ \\ ${ }^{1}$ Departman za biohemiju, Federalni univerzitet za agrokulturu, Abeokuta, Nigerija \\ ${ }^{2}$ Departman za zaštitu useva, Federalni univerzitet za agrokulturu, Abeokuta, Nigerija \\ ${ }^{3}$ Departman za biohemiju, Univerzitet Covenant, Sango Ota, Nigerija \\ ${ }^{4}$ Departman za biohemiju, Univerzitet Chrisland, Abeokuta, Nigerija \\ ${ }^{5}$ Departman za biohemiju, Univerzitet Landmark, Omu-Aran, Nigerija
}

\section{S A ŽETAK}

U ovoj studiji ispitivani su mogući efekti zavisni od doze ekstrakta Cannabis sativa (C. sativa) na ekspresiju gena za monoamino-oksidazu B (MAOB) i serotoninski receptor 2c (HTR2C), sa pokušajem korelacije trajanja upotrebe $\mathrm{i}$ tendencije ka neurodegeneraciji kod hroničnih korisnika marihuane. Pacovi muškog pola Wistar soja težine $90 \mathrm{~g} \pm 100 \mathrm{~g}$ tretirani su određenim dozama ekstrakta C. sativa u naftnom etru $(12,5,25$ i $50 \mathrm{mg} / \mathrm{kg}$ telesne mase) oralno. Izloženost je praćena u četvrtoj, osmoj i dvanaestoj nedelji za svaku od upotrebljenih doza, nakon čega je životinjama odstranjen mozak. Ekspresija gena određena je PCR reverznom transkriptazom. Kanabis je značajno smanjio $(p<0.05)$ relativnu ekspresiju MAOB $u$ četvrtoj nedelji. U osmoj nedelji kanabis je povećao relativnu ekspresiju MAOB za $60 \%$. Nakon 12 nedelja izlaganja kanabisu (C. sativa) u dozi od $50 \mathrm{mg} / \mathrm{kg}$ telesne mase primećeno je povaćanje od $80 \%$ u ekspresiji MAOB, u poređenju sa kontrolnom grupom. $U$ osmoj nedelji ekstrakt $C$. sativa doveo je do smanjenja u ekspresiji gena od $47 \%$. Međutim, prolongirano izlaganje (dvanaesta nedelja) ekstraktu značajno je povećalo $(\mathrm{p}<0,05)$ relativnu eksresiju HTR2C. Disregulacija MOAB gena izazvana kanabisom može biti jedan od mehanizama koji dovodi u vezu hroničnu upotrebu kanabisa sa padom kognitivnih funkcija i povećanom mogućnošću razvijanja neuroloških bolesti. Promene koje se zapažaju u ekspresiji gena, kao rezultat izlaganja visokim dozama ekstrkta $C$. sativa mogu delimično da objasne depresiju i tendenciju ka agresivnom ponašanju kod hroničnih korisnika marihuane.

Ključne reči: monoamino-oksidaza $\mathrm{B}$, ekspresija gena, serotoninski receptor $2 \mathrm{C}$, kanabis, neurodegeneracija 